\title{
Birds of Metauro river: a great ornithological diversity in a small Italian urbanizing biotope, requiring greater protection
}

\author{
Simone Ottorino Bai ${ }^{1}$, Marco Pantalone $e^{1,2 *}$
}

\begin{abstract}
This work is a qualitative analysis of the ornithological diversity in the area of Metauro river estuary and its lower course (Fano, Marche, Italy), a set of little wetlands of great birdlife conservation interest, defined in an urbanized context. Data collection took place through standardized censuses and ornithological observations in situ, from September 2010 to September 2020, integrated with an accurate bibliographic research on historical data. A total of 253 species have been recorded in the site; $59(23.32 \%)$ breed in the area, whereas 50 $(19.76 \%)$ species are vagrant and 72 species $(28.57 \%)$ are included in the Annex I of the Birds Directive (79/409/CEE). We determined the following indices: NP/P (ratio between the number of species non Passerines and Passerines $)=1.94$, O.V.I. (Ornithological Value Index $)=$ 20.80. The data relating to species of conservation interest and vagrant are reported in detail, in order to provide useful information for interventions for greater protection of the area. The high ornithological diversity and species richness highlighted in this study confirms the regional and national importance of the Metauro river estuary and the wetlands in its lower course, providing further data and giving support to more incisive conservation interventions, made necessary by the ever-increasing impact of disturbance and low naturalistic protection, that threatens the existence of the various and small biotopes of this important naturalistic area.
\end{abstract}

Key words: wetland; birds conservation; urban ecology; Metauro river.

Riassunto - Il presente lavoro è un'analisi qualitativa della diversità ornitologica relativa alla zona della foce del fiume Metauro e del suo basso corso (Fano, Marche, Italy), un insieme di piccole aree umide di grande interesse conservazionistico e avifaunistico, inserite in un contesto urbanizzato. La raccolta dei dati è avvenuta attraverso censimenti e osservazioni ornitologiche sul campo, condotte tra Settembre 2010 e Settembre 2020, integrate da un'accurata ricerca bibliografica sui dati storici. Sono state censite complessivamente per l'area 253 specie, di cui $59(23,32 \%)$ nidificanti, $50(19,76 \%)$ accidentali e $72(28,57 \%)$ incluse nell'Allegato I della Direttiva Uccelli (79/409/CEE). L'indice

'Associazione Naturalistica "Argonauta", Via P. Malatesta 2, 61032 Fano (PU), Italia.

E mail: argonautafano@yahoo.it

2 SOA, Stazione Ornitologica Abruzzese, c/o Museo De Leone, Riserva Naturale Regionale Lago di Penne, 65010 Penne (PE), Italia.

E mail: stazioneornitologicaabruzzese@gmail.com

* Corresponding author: pantalone.marco@libero.it

Received: 24 September 2020

Accepted for publication: 18 October 2020

Online publication: 1 February 2021
NP/P (rapporto tra il numero di specie non Passeriformi e Passeriformi) è risultato pari a 1,94 mentre l'I.V.O. (Indice di Valore Ornitologico) a 20,80 . Sono riportati nel dettaglio i dati relativi alle specie di interesse conservazionistico e accidentali, al fine di fornire informazioni utili per interventi di maggior tutela dell'area. L'elevata ricchezza e diversità ornitica evidenziata da questo studio conferma l'importanza regionale e nazionale della foce del Metauro e delle aree umide del suo basso corso. Si vogliono qui fornire ulteriori dati per interventi di conservazione più incisivi, resi necessari dai numerosi elementi di disturbo e di scarsa tutela naturalistica, che minacciano l'esistenza dei vari e piccoli biotopi di questa importante area naturalistica.

Parole chiave: aree umide; conservazione degli uccelli; ecologia urbana; fiume Metauro.

\section{INTRODUCTION}

The Metauro estuary and the river lower course has received little attention, despite numerous local publications dedicated in the last decades (Poggiani \& Dionisi, 1982, 1988a, 1988b, 2019; Poggiani et al., 2014). In this territory there are a series of aquatic habitats and biotopes which are of small extension but show extraordinary bird species richness, constituting a naturalistic corridor of great importance for the regional ecological network (Lawton et al., 2010; Harrison, 2016; Simoncini et al., 2018). All the area is inserted in an urban-industrial context in constant growth, which pose threats to the habitats before mentioned (McKinney, 2006; Simoncini et al., 2018). These habitats are particularly vulnerable to anthropogenic disturbance - e.g. water modeling in river's lower course, remote controlled drones, dog walks and kitesurfing (Krüger, 2016), together with illegal activities (e.g. hunting and fishing) - and changes caused by human activities, such as climate change (McKinney, 2002), colonization by alien species of animals and plants (Luken, 1997) and detrimental land management (e.g. mowing and pruning of the banks during reproductive period). Finally, the thermopluviometric regime changes led to the lowering of the groundwater, consequently reducing temporary and permanent wetlands, selected by migratory and wintering birds; this alteration also influenced the flood flows that maintained the gravelly habitats in the riverbed. The target of this study is an accurate analysis of the ornithological richness of the Metauro estuary and the first $5 \mathrm{~km}$ of his lower course and all 
the threats before mentioned underline the importance of greater protection and control. We here report an accurate assessment of the birds present in the study area, as a result of ten years of constant field observations combined with an accurate bibliographic research on historical and recent data. Finally, an in-depth description is provided for vagrant species and species of conservation priority.

\section{STUDY AREA}

The estuary of the Metauro river (Fano, Marche, Central Italy) is placed $13 \mathrm{~km}$ sud of Pesaro (central coordinates $13^{\circ} 3^{\prime} 18.18^{\prime \prime} \mathrm{E}-43^{\circ} 49^{\prime} 45.60^{\prime \prime} \mathrm{N}$ ). The study area includes $500 \mathrm{~m}$ South and North of the river estuary and goes up to $5 \mathrm{~km}$ inland following a SW-NE direction (river lower course, fields, lakes and ponds on both sides). The study area has an extension of 420 ha and belongs in the municipality of Fano. It includes a large part of a SAC (Special Area of Conservation; established within the meaning of Directive 92/43/CEE "Habitat") and SPA (Special Protection Area; established within the meaning of Directive 79/409/CEE) territory IT 5310022 "Fiume Metauro da Pian di Zucca alla foce". Therefore, an area of 330 ha within our study area $(78 \%$ of the total study area) is protected by national and international directives. A map of the area is shown in Figure 1.

The study area is composed of 7 main habitat types (the codes and denominations refer to those mentioned in Biondi et al., 2010b):

i. The estuary, henceforth termed "mouth", formed by accumulations of gravels and pebbles and often colonized by Atriplex prostrata. The aquatic vegetation is subject to continuous variations, attributable to habitat 3150: Natural eutrophic lakes with Magnopotamion vegetation or Hydrocharition (Biondi et al., 2010a, 2010b). The aquatic species representative of this habitat are Najas marina, Potamogeton crispus, Potamogeton nodosus and Spirodela polyrhiza. In chain contact with population of Bolboschoenus maritimus and Schoenoplectus tabernamontani. In the dry and raised part of the embankment there are extended population of exotic Arundo donax and Amorpha fruticosa.

ii. The river with his bed, characterized by the presence of gravelly deposits and river islets, which are generally colonized by annual and exotic species. The typical habitat is 3270 - Rivers with muddy banks with Chenopodion rubri p.p. and Bidention p.p. vegetation. (Biondi et al., 2010a).

iii. The riparian forest, dominated by the habitat 92A0: Tunnel forests of Salix alba and Populus alba galleries and the association Salici albae-Populetum nigrae (Tx. 1931) Meyer-Drees 1936 subass. populetosum nigrae (Tx. 1931) Meyer-Drees. (Biondi et al., 2010a). In this zone is always reported habitat 91E0* - Alluvial forests of Alnus glutinosa and Fraxinus excelsior (Alno-Padion, Alnion incanae, Salicion albae), which includes Ass. Rubo ulmifolii-Salicetum albae (Allegrezza et al., 2006) and the riparian forest Ass. Aro italici-Alnetum glutinosae (Pedrotti \& Gafta, 1995). In this biotope there is the highest density of exotic species such as Robinia pseudoacacia, Acer negundo, Ailanthus altissima, Amorpha fruticosa and Arundo donax.

iv. The lakes. In the study area there are 5 lakes, all originating from the excavation of the gravel in the alluvial terrace: Vicini Lake, Pascucci Lake, Solazzi Lake, Sorbini Lake and Tombaccia Lake (ap-
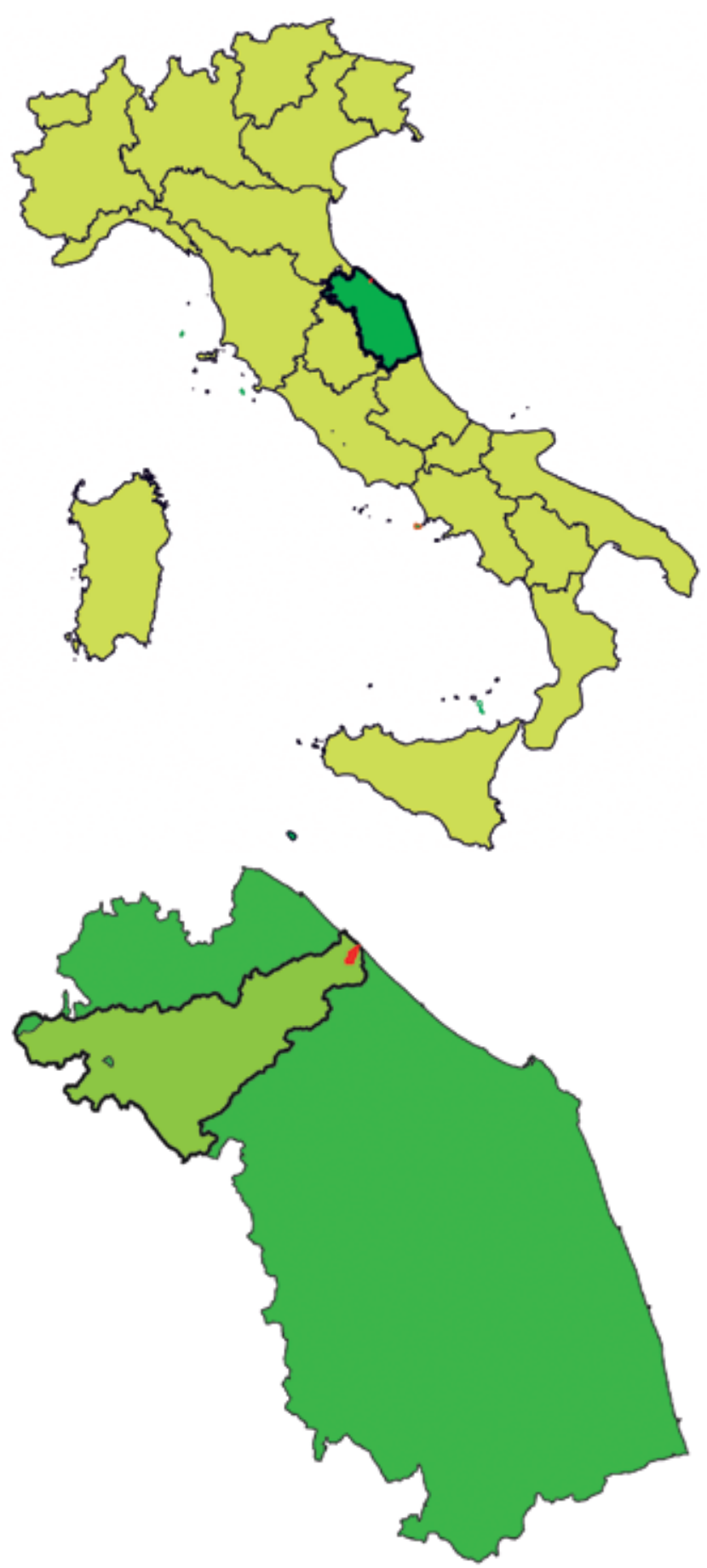

Fig. 1 - Cartographic framework of the study area, at national an regional level / Inquadramento cartografico dell'area di studio, a livello nazionale e regionale. 
proximately 30 ha total) (Poggiani \& Dionisi, 2019; Poggiani et al., 2014). These deep lakes are often colonized by Myriophyllum aquaticum. In addition to the latter, some native species, such as Potamogetum pectinatus, Potamogeton crispus, Potamogeton nodosus and other aquatic species such as Hippuris vulgaris. The shores of the unmanaged lakes are colonized by thick reeds of Phragmites australis. Beyond the reeds are present often sporadic specimens of Populus nigra and Populus alba below which Hedera helix, Rubus ulmifolius and Arundo plinii can be found.

v. The ponds - little areas originated from excavation activities and subsequent burial, becoming the wet areas of the Stagno Urbani and S. Rita ponds (Poggiani \& Dionisi, 2019; Poggiani et al., 2014) - and the flooded fields, called "guazzi" (little artificial wetlands, made and maintained for hunting reasons) (Biondi et al., 2002). It's a vegetation mosaic of deep and lentic waters, within which the following habitats are found: 3150 Natural eutrophic lakes with vegetation of Magnopotamion or Hydrocharition (Biondi et al., 2010b); 3260 Plains and mountain rivers with vegetation of Ranunculion fluitantis and Callitricho-Batrachion (Biondi et al., 2010b).

vi. The old settling tanks of the removed local sugar factory, and embankments, which are covered by Arundo plinii / Ass. Arundinetum plinianae (Biondi et al., 1992). The shrubby vegetation present is difficult to associate with a specific habitat and can be described as a mosaic with prevalence of species typical of the Class. Rhamno-Prunetea.

vii. The cultivated fields, most with cereals, grown in rotation with sunflower or alfalfa and with the presence of hedges and scattered trees. Some of these fields are outside the SCI-SPA area.

\section{MATERIALS AND METHODS}

\section{Data collecting}

Data were collected from September 2010 to September 2020 through standardized censuses (fixed transects, designed for counting bird species, crossed three times a week; Bibby, 2000) and not standardized observations in the study area. We used 10x binoculars, 30-60x spotting scope and digital cameras during the censuses. We combined an bibliographic research to the field observation, analyzing the numerous studies focused on the study area covering forty years. Finally, we considered online ornithological platforms www.ornitho.it and https://avibase. bsc-eoc.org, evaluating sightings case-by-case. In compliance with the rules of www.ornitho.it, for each observation we asked the data owner the authorization to publish the data. For each record we noted date of the observation and the name of the observer.

\section{Index calculation}

To calculate the Ornithological Value Index (O.V.I.) of the study area, the following algorithm was applied
(Massa et al., 2004; Termine et al., 2008; Simoncini et al., 2018):

$$
\begin{aligned}
& \quad \text { OVI }=S_{\text {Tot }}\left[\left(S_{\text {Spec1 }} \times 1\right)+\left(S_{\text {Spec } 2} \times 0.75\right)+\left(S_{\text {Spec } 3} \times 0.50\right)\right. \\
& +\left(S_{\text {non }- \text { Spec }} \times 0.25\right)+\left(S_{C R} \times 1\right)+\left(S_{E N} \times 0.75\right)+\left(S_{V U} \times 0.50\right) \\
& \left.\left.+\left(S_{L C} \times 0.25\right)+S_{147}\right)\right] \times 100^{-1}, \text { where }
\end{aligned}
$$

- $S T o t=$ total number of breeding bird species in the area;

- $S_{147}=$ number of breeding species included in the Annex I of the Birds Directive (09/147/CEE);

- $S_{\text {Spec } 1}, S_{\text {Spec } 2}, S_{\text {Spec } 3}, S_{\text {non-Spec }}=$ number of breeding species with SPEC values of 1, 2, 3 and non-SPEC, based on Birdlife International (2017);

- $S_{C R}, S_{E N} S_{V U}, S_{L C}=$ number of breeding species included in each of the four ranks provided by the Red List of Italian breeding birds (Gustin et al., 2019).

To calculate the non Passerines-Passerines ratio (NP/P) of the study area we obtained the number of non Passerines $(\mathrm{N}=167)$ and Passerines $(\mathrm{N}=86)$ from the total number of the species recorded $(\mathrm{N}=253)$, dividing the former by the latter.

\section{Taxonomy, nomenclature and abbreviations}

We followed for the scientific nomenclature, systematic and taxonomy the LISTA CISO-COI (Baccetti et al., 2019), which refers to the HBW-Birdlife Checklist (del Hoyo \& Collar, 2014, 2016; HBW \& Birdlife International, 2018). Regarding the English nomenclature, we referred to the BOU check-list of the birds of Britain (British Ornithologists' Union, 2013), integrated by the IOC World Bird List, when international English names differed from English vernacular names (Gill \& Donsker, 2019). To indicate phenology the following abbreviations have been used (adapted from Corso et al., 2012): A = vagrant: a species for which less than 5 records are known from the area (this is always followed by the number of records and their dating); $\mathrm{B}=$ breeding; $\mathrm{Mr}=$ regular migrant; $\mathrm{Mi}=$ irregular migrant (often due to lacking data or to variations in a species' abundance between past and recent years); $\mathrm{SB}=$ sedentary breeding: when the entire population breeding in the site is sedentary (opposite to migratory breeding); $\mathrm{W}=$ wintering; $\mathrm{Wi}=$ irregular wintering; ? = doubtful data (the status is uncertain, not proved by sufficient documentation). Other abbreviations used were: ad = adult; $f=$ female; im = immature; ind = individual or individuals; juv = juvenile; $\mathrm{m}=$ male $\mathrm{CY}=$ calendar year; ssp $=$ subspecies. Observations made by the authors during this study are indicated with $\mathrm{BP}=\mathrm{Bai}$ $\&$ Pantalone.

\section{RESULTS}

253 species are currently known from the mouth of the Metauro river and his lower course (online Supplementary File); 59 (23.32\%) of which breed certainty in the area, with further 6 species possible nesting. The 4 most represented families are: Anatidae (26 species), Scolopacidae (24 species), Laridae (21 species) and Accipritidae (12 species). The order Passeriformes makes 
up the $34.12 \%(\mathrm{~N}=86)$ of the total specific diversity, with an NP/P (ratio between the number of species non Passerines and Passerines) of 1.94. Vagrant species account for the $19.76 \%(\mathrm{~N}=50)$ of the total species number, 72 species $(28.57 \%)$ are included in the Annex I of the Birds Directive (79/409/CEE), 45 breeding species are mentioned in the Red List of Italian breeding birds as LC (Least Concern), 4 species are considered VU (Vulnerable) and 1 EN (Endangered). The O.V.I. (Ornithological Value Index) for breeding species equals to 20.80 .

\section{SPECIES OF EUROPEAN CONSERVATION CONCERN}

Species of conservation concern (i.e. included in Annex I Dir. CEE) are described focusing on their status in the study area.

Branta ruficollis Red-breasted Goose. Vagrant, with only a record known: 2 indd between 13 and 19 February 2012, Vicini Lake, during a period of heavy snow, along with a few dozen of Anser albifrons (Poggiani \& Dionisi, 2019).

Anser albifrons (ssp. flavirostris?) Greater Whitefronted Goose. Subspecies attribution needs further study. Vagrant, with 4 records known for the study area:

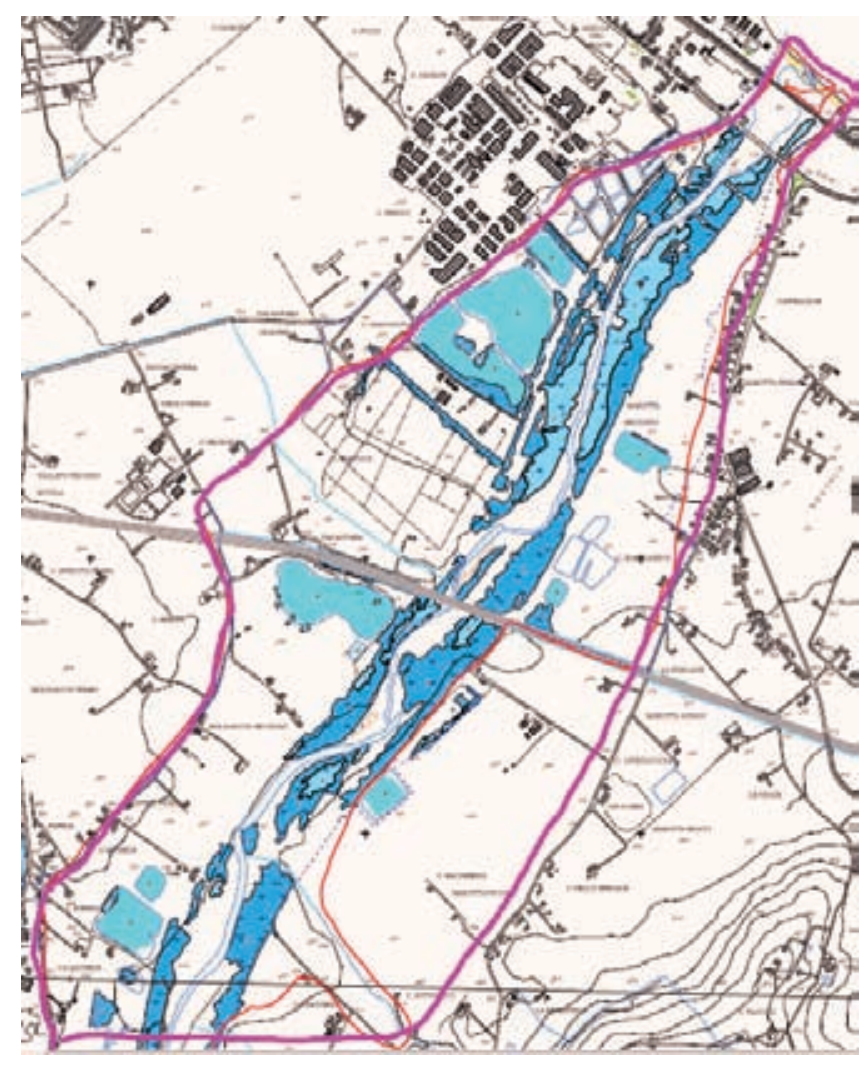

Fig. 2 - Cartographic framing of the study area (Metauro mouth and river lower course, Fano - PU). The cyclamen line delimits the study area (the red line, indicating the SCI SPA territory). / Inquadramento cartografico dell'area di studio (Foce del Metauro e basso corso del fiume, Fano - PU). La linea ciclamino delimita l'area di studio (spesso sovrapposta alla linea rossa, indicante il territorio della SIC ZPS) / Carta d'Italia 1:25.000, F. 269 Sezione III, modified.
- 1 ind on late February 1986, Metauro river (Poggiani \& Dionisi, 2019);

- 10-20 indd on mid-February 2012, over several days, Vicini Lake (BP);

- 1 ind on March 2012, Metauro river (Poggiani \& Dionisi, 2019);

- 2-3 indd on 11-01-2017, flight over the Vicini Lake (Poggiani \& Dionisi, 2019).

Cygnus cygnus Whooper Swan. Vagrant, with only one record: 5 indd (2 of them im) on 28-11-1984, Metauro's mouth (Pandolfi \& Santolini, 1985).

Aythya nyroca Ferruginous Duck. Regular migrant and regular wintering, at Stagno Urbani, Vicini Lake and others little lakes and ponds of the study area. Generally with few individuals but more frequently in the recent years. Species observed mainly on spring migration (between March and April) and on autumn migration (between August and November). Maximum number: 60 indd on 15-10-2016, Vicini Lake (BP).

Mergellus albellus Smew. Vagrant, with only one record: 1 ad f shot on 10-01-1982, at Metauro's mouth (Poggiani \& Dionisi, 2019).

Phoenicopterus roseus Greater flamingo. Regular migrant, more frequently observed in recent years. Observed at the Metauro's mouth, in flight in front of it and also in stopover in the lakes of the study area.

Caprimulgus europaeus European Nightjar. Regular migrant, occasionally observed in flight also at Metauro's mouth. Migration movements concentrated between the endApril and end-August. The breeding has not been confirmed.

Porzana parva Little Crake. Regular migrant (generally with few indd per year) occasionally observed also during autumn migration (between late August and November). Spring migrations is recorded between middle of March and the first week of May.

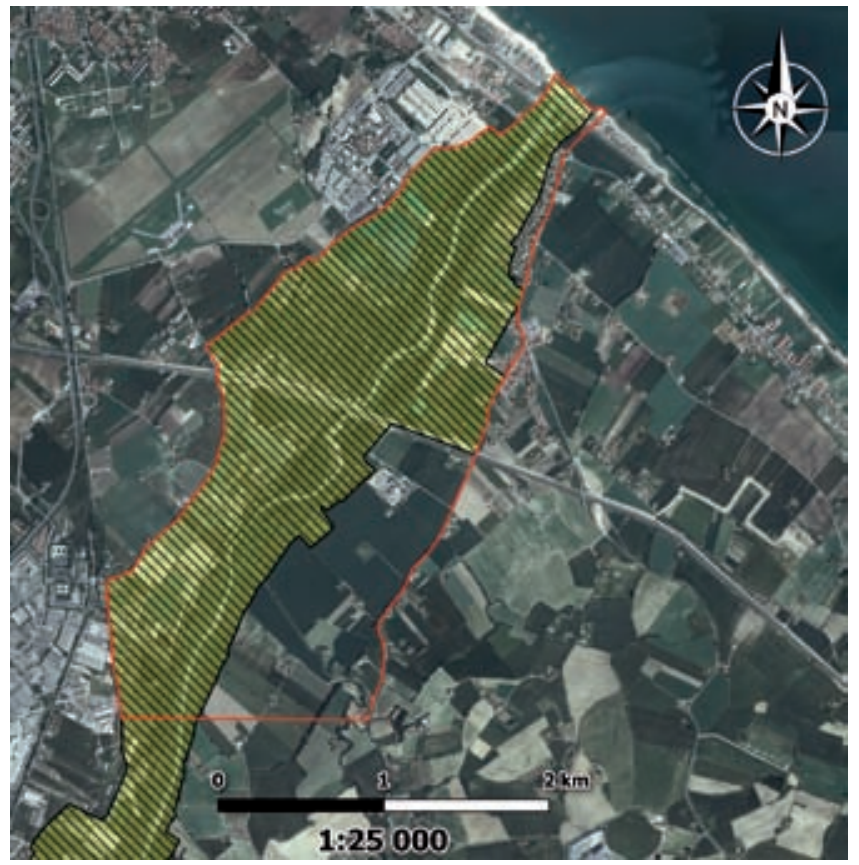

Fig. 3 - Map (2012) with orthophoto base of study area. / Carta (2012) con base ortofoto dell'area di studio. 
Porzana porzana Spotted Crake. Regular migrant (generally with 1 or 2 indd). The majority of individuals being counted during spring migration, between first days of March and end of April.

Grus grus Common Crane. Regular migrant, flying over the Metauro river - maximum number: 50 indd on 13-12-2002 (Poggiani \& Dionisi, 2019) - and its mouth. Rarely indd in stopover in the fields of the study area (maximum number: 20 indd on April 2014, S. Rita pond, over several days, BP). Spring migration between March and the middle of May, autumn migration between first week of September and the end of November.

Gavia immer Great Northern Loon. Vagrant, with only one record: 1 ind on March 1983, in a little lake in the study area (Poggiani \& Dionisi, 2019).

Gavia stellata Red-throated Loon. Vagrant, with 4 records known for the study area:

- 2 indd ( $1 \mathrm{ad} \mathrm{m}$ and $1 \mathrm{ad} \mathrm{f}$ ) collected on 25-12-1978,

Metauro's mouth (Poggiani \& Dionisi, 1991);

- 1 ind on 28-12-2016, Metauro's mouth (Poggiani \&

Dionisi, 2019);

- 1 ind on 5-1-2019, Metauro's mouth (BP);

- 1 ind from 1 to 3 November 2019, Metauro's mouth (BP).

Gavia arctica Black-throated Loon. Irregular migrant and irregular wintering, with a dozen total sightings. The species has been observed near the Metauro's mouth, remaining in the sea in front of the area for many days. Occasionally observed in small lakes in the study area. Observed between early November and early January.

Hydrobates pelagicus European Storm Petrel. Vagrant, with only one record: 1 ind on 2-2-1941, lower course/Metauro's mouth (Foschi, 1984).

Calonectris diomedea Scopoli's Shearwater. Vagrant, with only 2 records known:

- 2 indd on 11-11-2012, Metauro's mouth (Poggiani \&

Dionisi, 2019);

- 10 indd on 10-10-2015, Metauro's mouth (Poggiani \& Dionisi, 2019).

Ciconia nigra Black Stork. Regular migrant, even though quite scarce, with increasing number of observations in recent years. Observed usually flying over the area, and occasionally seen in the river, Stagno Urbani and Vicini Lake probably using them as stopover sites. Species observed mainly on spring migration (between mid-March and end-June).

Ciconia ciconia White Stork. Regular migrant, even though quite scarce in the study area. It has been observed in migration flight (mainly in spring, between midFebruary and end-May). Rarely it used the fields South of the river as stopover sites.

Plegadis falcinellus Glossy Ibis. Regular migrant, observed every year in the ponds of the study area, usually with 1-3 indd. (maximum number: 14 indd on 17-042015, Vicini lake, BP). Species observed mainly during spring migration (between end-March and end-May), rarely postbreeding movements at end-July. An ind of this species - ringed on May 2017 in France (Tour de Valat, Camargue) - was observed in the study area on May 2019 (BP).
Platalea leucorodia Eurasian Spoonbill. Regular migrant, with increasing number of observations in recent years. Usually single ind or small flocks use the ponds of the study area as a stopover site, with maximum number of 9 indd on 22-7-2001 in Metauro ponds (Poggiani \& Dionisi, 2019). Species observed mainly during spring migration (between the middle of March and the end of May), with rare post-breeding observations between June and October: the largest flock counts 19 indd on 10-92015, Metauro's mouth (Poggiani \& Dionisi, 2019). An ind ringed on 2008 in Retszilas (Fejér, Hungary) was observed in the study area on March 2019 (BP). Another ind of this species, ringed on April 2017 in Ravenna (Italy), was observed in the study area on April 2019 (BP).

Botaurus stellaris Eurasian Bittern. Regular migrant and irregular wintering, even though quite scarce in the study area, observed in the ponds, occasionally also wintering (between end-December and end-February).

Ixobrychus minutus Little Bittern. Regular migrant and irregular breeding, it's difficult to confirm the breeding every year, because of the elusiveness of the species and the difficulty of monitoring its habitat. Species observed mainly on spring migration, mostly in May.

Nycticorax nycticorax Black-crowned Night Heron. Regular migrant, with increasing number of observations in recent years. The presence of a good number of juv could indicate the dispersions from nearby breeding areas in the middle course of Metauro river. Species observed mainly during spring migration (between end-March and early April), rarely during autumn migration (between end-August and early October).

Ardeola ralloides Squacco Heron. Regularly observed during spring migration, even though quite scarce (rarely more than 2 indd in a pond). More consistently observed during spring migration, between end-March and endMay.

Ardea purpurea Purple Heron. Regular migrant, that used - even for some weeks - the ponds of the study area and Vicini Lake as a stopover site. Spring migration occurs between early March and early June (mostly observed in April and May), while autumn migration between July and October (with a peak in September).

Ardea alba Great Egret. Regular migrant, irregular wintering, with increasing number of observations in recent years. Commonly seen between September and June, rarely in July.

Egretta garzetta Little Egret. Regular migrant and regular wintering. Observed throughout the entire year, the individuals may come from nearby breeding sites.

Pelecanus onocrotalus White Pelican. Vagrant, with only one record: 1 ind on 2001, Metauro's mouth (Poggiani \& Dionisi, 2019).

Microcarbo pygmaeus Pygmy Cormorant. Regular migrant and regular wintering with increasing number of observations in recent years. In the last decade, it became common at Metauro's mouth and especially at Vicini Lake and Stagno Urbani: here, since 2011, a roost has formed (Giacchini et al., 2019), reaching up to 200 indd (BP). Usually observed between October and April (rarely in September and May). There are also post-breeding observations (July-August). 
Phalacrocorax aristotelis European Shag. Vagrant, with only 3 records known:

- 1 ind on 29-10-2014, Metauro's mouth (R. Ceccucci in www.ornitho.it consulted on 30 August 2020);

- 1 ind on 2-01-2016, Metauro's mouth (C. Montevecchi in www.ornitho.it consulted on 30 August 2020);

- 1 im on 28-06-2020 Metauro's mouth (BP).

Burhinus oedicnemus Eurasian Stone-curlew. Vagrant, with only 2 records known:

- 1 ind on 13-05-2003, gravely bed of Metauro river (Poggiani \& Dionisi, 2019);

- 1 ind on 06-01-2015, rocks North of Metauro's mouth (Poggiani \& Dionisi, 2019).

Himantopus himantopus Black-winged Stilt. Regular migrant and regular breeding. It uses $\mathrm{S}$. Rita ponds as breeding site - maximum number: 11 nests on 2005 (Poggiani \& Dionisi, 2019) - and especially Stagno Urbani (from 2007, with at least 9 nests in 2017, BP). Spring migration starts in mid-March and post-breeding migration ends in September. An ind of this species, ringed on 2002 in Cervia (Ravenna, Italy), was observed in the study area on 2015 (BP).

Recurvirostra avocetta Pied Avocet. Irregular migrant, more common in past decades, with only few recent observations for the study area.

Pluvialis apricaria European Golden Plover. Regular migrant and irregular wintering, observed every year during the study period, in the Metauro's mouth between end-October and early March (maximum number: 12 indd on 14-10-2018, BP) or in stopover in the fields near S. Rita ponds (from December to February).

Charadrius alexandrinus Kentish Plover. Regular migrant and regular wintering, even though quite scarce in the study area. The few observations were related to the Metauro's mouth, with most indd probably coming from nearby breeding sites.

Limosa lapponica Bar-tailed Godwit. Vagrant, with only 3 records known:

- 1 ad f on 11-09-1970, Metauro's mouth (Poggiani \& Dionisi, 2019);

- 1 ind on 14-09-2003, Metauro's mouth (Poggiani \& Dionisi, 2019);

- 1 ind on 15-09-2013, Metauro's mouth (Poggiani \& Dionisi, 2019).

Calidris pugnax Ruff. Regular migrant, observed both during migration movements (maximum number 10 indd on 12-05-2019, Metauro's mouth, BP) and during stopover in the ponds (up to 19 indd, Stagno Urbani, BP). Mainly observed during spring migration (between last week of February and mid-May), rarely during autumn migration (September).

Gallinago media Great Snipe. Irregular migrant, quite scarce, mainly observed in Stagno Urbani and rarely in S. Rita ponds.

Tringa glareola Wood Sandpiper. Common regular migrant, quite common during migration movements, mainly in stopover in the ponds of the study area. Spring migration between early March and end-May, less common during post-breeding migration (end-July and September).
Glareola pratincola Collared Pratincole. Vagrant, with only one record known: 1 ind on 29-4-2019, S. Rita ponds (BP).

Chroicocephalus genei Slender-billed Gull. Irregular migrant, with all the observations in the study area during the last decade.

Hydrocoloeus minutus Little Gull. Regular migrant and irregular wintering, quite scarce in the study area in recent years. Usually near the Metauro's mouth, occasionally observed in Stagno Urbani.

Ichthyaetus audouinii Audouin's Gull. Vagrant, with only one record: $1 \mathrm{im}$ in 3CY on 6-6-2020, Metauro's mouth (BP).

Ichthyaetus melanocephalus Mediterranean Gull. Regular migrant and regular wintering, with increasing number of observations in recent years. Maximum number: 250 indd on 3-11-2017, rocks south of the Metauro's mouth (Poggiani \& Dionisi, 2019).

Gelochelidon nilotica Gull-billed Tern. Irregular and rare migrant, vagrant with only 2 records known - 2014 and 2019 - until June 2020, when the observations increased at Metauro's mouth. Maximum number: 6 indd on 14-06-2020, Metauro's mouth (BP).

Hydroprogne caspia Caspian Tern. Irregular migrant, quite scarce in the study area but more common in recent years, mainly at Metauro's mouth and rarely at Vicini Lake.

Thalasseus sandvicensis Sandwich Tern. Regular migrant and regular wintering, more common in recent years. Maximum number: about 70 indd on 19-11-2016, Metauro's mouth (Poggiani \& Dionisi, 2019).

Sternula albifrons Little Tern. Irregular migrant, rare in the study area. Observed only at Metauro's mouth.

Sterna hirundo Common Tern. Regular migrant, even though quite scarce, observed usually at Metauro's mouth and occasionally also in some ponds of the study area. Migration occurring between early August and end October.

Chlidonias hybrida Whiskered Tern. Regular migrant, even though quite rare in the study area, observed both in ponds and Metauro's mouth.

Chlidonias niger Black Tern. Regular migrant, even though quite scarce in the study area, observed both in ponds and Metauro's mouth.

Asio flammeus Short-eared Owl. Vagrant, with only one record: 1 ind on 18-10-2018, flying over Stagno Urbani (BP).

Pandion haliaetus Western Osprey. Regular but scarce migrant, generally with few indd per year, observed both at Metauro's mouth and in some lakes of the study area.

Pernis apivorus European Honey-buzzard. Regular migrant, observed in migration periods, also in small flocks.

Circaetus gallicus Short-toed Snake Eagle. Vagrant, with only one record: 1 ind on 19-03-2016, flying over Stagno Urbani (V. Lucchetti, pers. comm., bird photographed). The species is probably underestimated for the study area, especially during migration.

Hieraateus pennatus Booted Eagle. Vagrant, with only one record: 1 ind on 15-05-2015, fields near S. Rita ponds (Poggiani \& Dionisi, 2019). 
Circus aeruginosus Western Marsh Harrier. Regular migrant, observed mainly during migration or hunting in the fields near the river, sometimes also at Metauro's mouth.

Circus cyaneus Hen Harrier. Regular migrant, irregular and rarely wintering, observed during migration or hunting in the fields near the river.

Circus macrourus Pallid Harrier. Vagrant, with only one record: 1 ad $\mathrm{m}$ on 20-04-2017, fields near S. Rita ponds (Poggiani \& Dionisi, 2019).

Circus pygargus Montagu's Harrier. Regular migrant, scarce during migration, sometimes hunting in the southern fields of Metauro river.

Milvus milvus Red Kite. Irregular and rare migrant, observed only during migration along the river.

Milvus migrans Black Kite. Regular migrant, scarcely observed only during migration.

Coracias garrulus European Roller. Vagrant, with only one record: 1 ind on 25-05-1983, in the fields near Metauro river (Poggiani \& Dionisi, 2019).

Alcedo atthis Common Kingfisher. Regular migrant, regular wintering and regular breeding, in the last decade decreased due to the destruction of the escarpments (for hydraulic arrangements). The species feeds along the river and at Metauro's mouth, but also in the lakes and ponds of the study area.

Falco naumanni Lesser Kestrel.Vagrant, with only one record: 1 ind on 25-03-2017, fields near S. Rita ponds (Poggiani \& Dionisi, 2019).

Falco vespertinus Red-footed Falcon. Irregular and rare migrant in the study area, observed only during migration, probably due to the absence of suitable stopover and hunting areas (such as near aviation fields).

Falco peregrinus Peregrine Falcon. Regular migrant and regular wintering. Seen during migration and juvenile dispersal, some indd - breeding outside the study territory - sometimes hunt in the area of Metauro's mouth.

Lanius collurio Red-backed Shrike. Regular migrant and regular breeding, even though quite scarce in the study area. The breeding sites along the hedges near the fields South-West of Metauro.

Periparus ater Coal Tit. Irregular migrant and irregular wintering, rare in study area, sometimes observed in the parks of the study area.

Acrocephalus melanopogon Moustached Warbler. Regular migrant and irregular wintering, decreasing in the last decade, frequents in water reeds of ponds and lakes of the study area. Observed on spring migration from midFebruary to early April, on autumn migration from midOctober to mid-November. Sometimes the species winter from mid-December to end-January.

Luscinia svecica Bluethroat. Very rare irregular migrant, observed in Stagno Urbani and S. Rita ponds with both of ssp: svecica and cyanecula (Poggiani \& Dionisi, 2019).

Ficedula albicollis Collared Flycatcher. Regular but scarce migrant, usually seen in the ponds near the river during stopover, also for several days. Species observed mainly during spring migration (April-May), rare during autumn migration.
Emberiza hortulana Ortolan Bunting. Irregular migrant, very rare in the study area. The individuals observed were on migration or coming from nearby breeding sites.

\section{SYSTEMATIC LIST OF VAGRANT SPECIES}

Vagrant species (i.e. species with less than 5 known from the area) are here described, focusing on their occurrence in the area.

Netta rufina Red-crested Pochard. Four records known for the study area:

- 1 ad $\mathrm{m}$ shot on december 1977, ponds (Poggiani \& Dionisi, 2019);

- 1 ad m on 30-01-1994, ponds (Poggiani \& Dionisi, 2019);

- 1 ad f on April 1996, Stagno Urbani (Poggiani \& Dionisi, 2019);

- $1 \mathrm{ad} \mathrm{m}$ on 25-11-1997, ponds (Poggiani \& Dionisi, 2019).

Aythya marila Greater Scaup. Two records known:

1 ad f shot on 12-11-1978, ponds, specimen preserved (Poggiani \& Dionisi, 2019);

1 ad m shot on 20-11, 1980, Metauro's mouth, specimen preserved (Poggiani \& Dionisi, 2019);

Melanitta nigra Common Scoter. Three records known for the study area:

- 1 ad m collected on 20-11-1984, Metauro's mouth (Poggiani \& Dionisi, 2019);

- 1 ad m on 15/28-1-2015, North Metauro's mouth (BP);

- 1 ind between 4 and 5 December 2016, Metauro's mouth (BP).

Clangula hyemalis Long-tailed Duck. Only one record: 1 ind shot on 10-01-1990, Metauro's mouth (Poggiani \& Dionisi, 2019).

Mergus merganser Common Merganser. Four records known for the study area:

- 1 ind on 3-1-1981, ponds (Antognoni \& Felicetti, 1982);

- 1 ad $\mathrm{m}$ on 20-12-1983, ponds (Poggiani \& Dionisi, 2019);

- 1 ad f on 30-11-2017, Metauro's mouth (Poggiani \& Dionisi, 2019);

- 1 ad m on 20-1-2019, Metauro's mouth (BP).

Podiceps grisegena Red-necked Grebe. Only one record: 1 ad $\mathrm{m}$ shot on 5-1-1989, lake in the study area, specimen preserved (Poggiani \& Dionisi, 2019).

Ardenna gravis Great Shearwater. Only one record: 1 ind on 20-10-2019, Metauro's mouth (BP). If accepted by the COI (Italian Ornithological Commission), it woud the $1^{\text {st }}$ national record after 1950 (Brichetti \& Fracasso, 2018) and the $2^{\text {nd }}$ absolute record for Italy, in addition to being the $1^{\text {st }}$ for all the Adriatic Sea and one of the very few for all the Eastern Mediterranean (as reported in https://avibase.bsc-eoc.org consulted on 1 April 2020).

Puffinus yelkuan Yelkouan Shearwater. Only one record: 1 ind on 8-12-2018, Metauro's mouth (BP). This species may be underestimated for its attitude to fly offshore. 
Vanellus gregarius Sociable Lapwing. Only one record: 1 ind on 18-3-2007, S. Rita ponds (Poggiani \& Dionisi, 2019).

Charadrius asiaticus Caspian Plover. Only one record: $1 \mathrm{f}$ shot on 12-11-1887, Metauro, specimen preserved (Salvadori, 1887). The species have only four records for Italy and this, reported here, was the first national observation in Italy (Brichetti \& Fracasso, 2015, 2018).

Calidris canutus Red Knot. Only one record: 1 juv shot on 25-12-1980, Metauro's mouth (Poggiani \& Dionisi, 2019).

Calidris alba Sanderling. Only one record: 1 ind between 18 and 22 September 2020, Metauro's mouth and South beach (BP; V. Dionisi, pers. comm).

Phalaropus fulicarius Red Phalarope. Only one record: 1 ad f shot on 24-12-1979, Metauro's mouth (Poggiani \& Dionisi, 2019).

Rissa tridactyla Black-legged Kittiwake. Only 3 records known for the study area:

- 2 indd on 11-11-2012, Metauro's mouth (Poggiani \& Dionisi, 2019);

- 1 ind on 12-09- 2016, Metauro's mouth (R. Ceccucci in www.ornitho.it consulted on 30 August 2020);

- 1 ind on 13-05-2019, Metauro's mouth (BP).

Larus marinus Great Black-backed Gull. Four records known:

1 juv on 12-12-2016, South of the Metauro's mouth (Poggiani \& Dionisi, 2019);

1 ind on 4-2-2017, South of the Metauro's mouth (Poggiani \& Dionisi, 2019);

1 ind on 31-1/1-2-2018, South of the Metauro's mouth (Poggiani \& Dionisi, 2019);

1 ind on 27-2-2019, South of the Metauro's mouth (Poggiani \& Dionisi, 2019).

Larus hyperboreus Glaucous Gull. Only one record: 1 ind on 18-12-1959, lower course of Metauro (Foschi, 1984). It's the $1^{\text {st }}$ regional record (Giacchini, 2003) and the species has been recorded only 22 times nationally (Brichetti \& Fracasso, 2006, 2018).

Stercorarius longicaudus Long-tailed Jaeger. Only one record: 1 ind on 20-10-1932, lower course of Metauro (Foschi, 1984).

Accipiter gentilis Northern goshawk. Only one record: 1 juv on 20-1-2013, Stagno Urbani, riparian wood (Poggiani \& Dionisi, 2019).

Lanius excubitor Great grey Shrike. Only 2 records known for the study area:

- 1 ind on May 1985, lower course of Metauro (Poggiani \& Dionisi, 2019).

- 1 ind on May 1986, lower course of Metauro (Poggiani \& Dionisi, 2019).

Lanius senator Woodchat Shrike. Only one record: 1 ind on 5-5-2009, fields near S. Rita ponds (Poggiani \& Dionisi, 2019).

Hippolais icterina Icterine Warbler. Only one record: 1 ind on 22-08-1998, captured during ringing activities, Stagno Urbani (Poggiani \& Dionisi, 2019).

Locustella naevia Grasshopper Warbler. Only one record: 1 ind on 11-09-1934, lower course of Metauro (Foschi, 1984).
Panurus biarmicus Bearded Reedling. Only one record: 1 ind on 20-1-2013, Stagno Urbani (Poggiani \& Dionisi, 2019).

Sylvia borin Garden Warbler. Only one record: 1 ind on 12-05-2005, Stagno Urbani (Poggiani \& Dionisi, 2019).

Pastor roseus Rosy Starling. Only one record: 1 ind on 2-6-2018, Stagno Urbani (BP).

Bombycilla garrulus Bohemian Waxwing. Two records known:

- 3 indd on 28-1-2009, Stagno Urbani (Poggiani \& Dionisi, 2019);

- 1 ind on 12-12-2012, Stagno Urbani (Poggiani \& Dionisi, 2019).

- Passer hispaniolensis Spanish Sparrow. Only 2 records known:

- 1 ind on 20-12-2008, in the fields near Metauro river (Poggiani \& Dionisi, 2019);

- 1 ind on 2015, between 25-01 and 03-02, Stagno Urbani (BP).

- 1 ind on 07-03-2018, Stagno Urbani (BP).

Emberiza cia Rock Bunting. Only one record: 1 ind on 15-03-1984, riparian woods (Poggiani \& Dionisi, 2019).

Plectrophenax nivalis Snow Bunting. Three records known for the study area:

- 2 indd on 26-11-1981, beach North of Metauro's mouth (Antognoni \& Felicetti, 1982);

- 4 indd on 15-11-1987, beach North of Metauro's mouth (Poggiani \& Dionisi, 2019);

- 2 indd on 4-12-2005, beach North of Metauro's mouth (Poggiani \& Dionisi, 2019).

Emberiza pusilla Little Bunting. Only one record: 1 ind shot on 9-10-1959, lower course of Metauro (Foschi, 1984).

\section{DISCUSSION}

The species reported from the study area $(\mathrm{N}=253)$ represent the $45.42 \%$ of the species recorded in Italy $(\mathrm{N}=557$; Fracasso et al., 2018) and the $75.07 \%$ of the species known for Marche region $(\mathrm{N}=337$; Giacchini, 2003). Moreover, a new regional record has been added (i.e. Ardenna gravis). We reported a remarkable ornithological richness, especially considering the small size of the study area. The species richness could be related to the variety and number of diverse habitats (Poggiani et al., 2004, 2007), which allow numerous bird species to find optimal conditions to look for food, in different small and fragmented environments and ecological niches. Moreover, the area is located along an important internal flyway - with the Metauro taken as a reference point - and along the Adriatic coast, nearby the important Conero hotspot for waders and also for raptors (Borioni, 1993). The areas benefit also from the contingents in arrival from the Po Delta or opposite, from Croatia (Spina \& Volponi, 2008). The great ornithological relevance of the study area contrasts significantly with its medium-high urbanization and low industrialization, as well as being subjected to considerable, varied and constant disturbances (hunting, fishing, anthropogenic 
disturbance, impacting sporting activities and riverbed work). Taking this into account, adequate conservation and protection of the study area proves to be fundamental. The preservation of the various habitats could provide important areas for bird species, while keeping high the connectivity between the various landscapes, a crucial feature for the conservation of migratory birds (Taylor et al., 1993; Tischendorf \& Fahrig, 2000; Levey et al., 2005; Mitchell et al., 2013), also supported from the low O.V.I. 20.80 for breeding species, that compared to the high species richness $(\mathrm{N}=253)$ show the importance of the study area as a stopover site for migratory birds at regional and national level. For these reasons a greater safeguard to the study area could help maintaining and safeguarding the whole regional ecological network, with important consequences for all the supra-regional migratory belt of the middle Adriatic (Premuda et al., 2008). Greater protection and attention could lead to obtaining a stronger connection between the areas already recovered (lakes and ponds) with those still in good natural conditions, in order to recreate an important uncontaminated habitat (Lawton et al., 2010; Harrison, 2016; Simoncini et al., 2018) and bringing great benefits also to the urban matrix (Collins et al., 2000; McKinney, 2006). Even though most of the study area is in the SPA and SCI area, it must be noted that only a portion of it is actually protected (that relating to fenced areas). The anthropogenic disturbance problems already mentioned, hinder the possibility of many species to move between the various habitats, increasing the disconnection of the little biotopes in the area (Lawton et al., 2010; Harrison, 2016; Simoncini et al., 2018). Therefore, we recommend increasing the controls in such an important area, reducing anthropic disturbance and avoiding hunting, fishing and hydraulic interventions on the river. In conclusion, a better management of the area would lead not only to the safeguarding of the ornithic richness but also to gain good economic improvements for the local community, leading to a significant increase in natural tourism, today a totally neglected resource.

\section{Acknowledgements}

They are very grateful to Luciano Poggiani and Christian Cavalieri for providing data on historical record releted to the study area. The authors warmly thank to Massimo Pellegrini for the critical rereading, help and availability. They also thank the ornithologists and birders who provided observations, carried out with passion and competence: Virgilio Dionisi, Roberto Ceccucci, Cristian Montevecchi and Vanessa Lucchetti. A thank also for Andrea Corso, Mario Posillico, Rosario Balestrieri and Federico Fanesi for their help and support in some identifications. They are grateful also to Marco Bianchini for the help and availability with the cartography. A very special thanks go to naturalistic association "Argonauta Fano" and all is members for teaching people - for many decades - how to actively help protecting the Metauro river, his mouth, the ponds and lakes in the study area.

\section{REFERENCES}

Allegrezza M., Biondi E. \& Felici S., 2006 - A phytosociological analysis of the vegetation of the central Adriatic sector of the Italian peninsula. Hacquetia 5/2: 135-175.

Antognoni A. \& Felicetti A., 1982 - Osservazioni sul passo degli Uccelli migratori in un tratto della costa adriatica (foce del F. Metauro, Pesaro). U.D.I., A. VII (3): 150-154.

Baccetti N., Fracasso G. \& Commissione Ornitologica Italiana, $2019-$ Lista CISO-COI degli uccelli italiana (seconda bozza). <https:// ciso-coi.it/news/lista-ciso-coi-2019-degli-uccelli-italiani-secondabozza-settembre-2019/>

Bibby C. J., Burgess D. \& Hill D. A., 2000 - Bird census techniques. Academic Press, London.

Biondi E., Allegrezza M., Baldoni M., Casavecchia S., Pinzi M. \& Taffetani F., 2010a - Le Serie di Vegetazione della regione Marche: In: Blasi C. (ed.). La Vegetazione d'Italia. Palombi \& Partner S.r.l., Roma: 231-255.

Biondi E., Blasi C., Burrascano S., Casavecchia S., Copiz R., Del Vico E., Galdenzi D., Gigante D., Lasen C., Spampinato G., Venanzoni R. \& Zivkovic L., 2010b - Italian Interpretation Manual of the 92/43/EEC Directive habitas. Ministry of Environment, Land and Sea (Italy), Roma.

Biondi E., Brugiapaglia E., Allegrezza M. \& Ballelli S., 1992 - La vegetazione del litorale marchigiano (Adriatico centro-settentrionale). Colloques Phytosociologiques, 19: 429-460.

Biondi E., Casavecchia S. \& Radetic Z., 2002 - The "guazzi" vegetation and the plant landscape of the alluvial plane of the last stretch of the Musone River (Central Italy), Fitosociologia, 39 (1):45-70.

Birdlife International, 2017 - European birds of conservation concern: populations, trends and national responsabilities. Birdlife international, Cambridge, UK.

Borioni M., 1993 - Rapaci sul Conero: studio sulla migrazione prenuziale degli uccelli rapaci diurni nel parco del Conero, negli anni 1987, 1988, 1989 e 1990. Parco nazionale del Conero, Ancona.

Brichetti P. \& Fracasso G., 2006 - Ornitologia italiana, vol 3, Stercorariidae-Caprimulgidae. Alberto Perdisa Editore, Bologna.

Brichetti P. \& Fracasso G., 2015 - Ornitologia italiana, vol 9, Emberizidae-Icteridae. Edizioni Belvedere, Latina.

Brichetti P. \& Fracasso G., 2018 - Birds of Italy (1). Edizioni Belvedere, Latina.

British Ornithologists' Union (BOU), 2013 - The British List: a checklist of birds of Britain. $8^{\text {th }}$ ed. Ibis, 155: 635-676.

del Hoyo J. \& Collar N. J., 2014 - HBW and BirdLife International Illustrated Checklist of the Birds of the World. Vol. 1: Non-Passerines. Lynx Edicions, Barcellona.

del Hoyo J. \& Collar N. J., 2016 - HBW and BirdLife International Illustrated Checklist of the Birds of the World. Vol. 2: Passerines. Lynx Edicions, Barcellona.

Collins J. P., Kinzig A., Grimm N. B., Fagan W. F., Hope D., Wu J. \& Borer E.T., 2000 - A new urban ecology. American Scientist, 88: 416-425.

Corso A., Penna V., Gustin M., Maiorano I. \& Ferrandes P., 2012 Annotated checklist of the birds from Pantelleria Island (Sicilian Channel): a summary of the most relevant data, with new species for the site and Italy. Biodiversity Journal, 3 (4): 407-428.

Foschi U. F., 1984 - Catalogo della collezione del Museo Ornitologico "Ferrante Foschi". Comune di Forli, Tipografia Faenza.

Fracasso G., Janni O., Fulco E. \& Liuzzi C. (eds.), 2018 - Commissione Ornitologica Italiana (COI). Report 27. Avocetta, 42: 45-53.

Giacchini P., 2003 - Check list degli uccelli delle Marche. Rivista Italiana di Ornitologia. 73 (1): 25-45.

Giacchini P., Pascucci M., Cavalieri C., Fanesi F., Feriozzi D., Gambelli P., Tarsetti C. \& Zazzini A., 2019 - Svernamento di Cormorano (Phalacrocorax carbo) e Marangone minore (Microcarbo pygmaeus) nelle Marche: evoluzione e aggiornamenti. XX Convegno Italiano di Ornitologia, Napoli.

Gill F. \& Donsker D. (eds.), 2019 - IOC World Bird List (v 9.2). < Doi 10.14344/IOC.ML.9.2><http://www.worldbirdnames.org>

Gustin M., Nardelli R., Brichetti P., Battistoni A., Rondinini C., Teofili C., (eds.), 2019 - Lista Rossa IUNC degli uccelli nidificanti in Italia 2019. Comitato Italiano IUNC e Ministero dell'Ambiente e della Tutela del Territorio e del Mare, Roma. 
Harrison L., 2016 - Connectivity and ecological networks. LI Technical Information Note.

HBW \& BirdLife Interntional, 2018 - Handbook of the birds of the world and BirdLife International digital checklist of the birds of world. Ver. 3. <http://datazone.birdlife.org/specoies/taxonomy>

Krüger T., 2016 - On the effects of kitesurfing on waterbirds - a review. Informationdienst Naturschutz Niedersachsen, 36: 3-64.

Lawton J. H., Brotherton P. N. M., Brown V. K., Elphick C., Fitter A. H., Forshaw J., Haddow R. W., Hilborne S., Leafe R. N., Mace G. M., Southgate M. P., Sutherland W. J., Tew T. E., Varley J. \& Wynne G. R., 2010 - Making Space for Nature: a review of England's wildlife sites and ecological network. Report to Defra.

Levey D. J., Bolker B. M., Tewksbury J. J., Sargent S. \& Haddad N. M., 2005 - Effects of landscape corridors on seed dispersal by birds. Science, 309: 146-148.

Luken J. O., 1997 - Conservation in the context of non-indigenous species. In: Schwarz M. W. (ed.). Conservation in Highly Fragmented Landscapes. Chapman and Hall: 107-116.

Massa B., Furia M., Bombace M. \& De Domenico R., 2004 - Proposta di gestione integrata delle aree protette dei Sicani. Naturalista siciliano, 28: 431-455.

McKinney M. L., 2002 - Urbanization, Biodiversity, and Conservation. BioScience, 52: 883-890.

McKinney M. L., 2006 - Urbanization as a major cause of biotic homogenization, Biological Conservation, 127: 247-260.

Mitchell M. E., Bennett E. \& Gonzalez A., 2013 - Linking landscape connectivity and ecosystem service provision: current knowledge and research gaps. Ecosystems, 16: 894-908.

Pandolfi M. \& Santolini R., 1985 - Osservazioni di Uccelli marini nel tratto di litorale adriatico tra le foci del F. Uso (Bellaria, Forli) e Metauro (Fano, Pesaro). Rivista Italiana di Ornitologia, Milano, 55 (1-2): 31-40.

Pedrotti F. \& Gafta D., 1995 - Tipificazione di due nuove associazioni ripariali per la Penisola italiana (Aro italici-Alnetum glutinosae ass. nova e Hyperico hircini-Alnetum glutinosae). Documents Phytosociologiques, 15: 413-415.

Poggiani L. \& Dionisi V, 1982 - L'avifauna del Metauro. Osservazioni condotte nel basso corso del Metauro nel periodo 1980-1982. Centro Studi Argonauta - W.W.F. Fano, Fano.

Poggiani L. \& Dionisi V., 1988a - Uccelli del bacino del Metauro. Centro Studi Argonauta. Fano.

Poggiani L. \& Dionisi V., 1988b - Prima valutazione sulla consistenza degli uccelli acquatici e di zone umide nella bassa valle del Metauro (PS). Atti I Seminario Italiano Censimento Faunistico: 230-235.

Poggiani L. \& Dionisi V., 1991 - Strolaga minore Gavia stellata nelle acque marine marchigiane. Uccelli d'Italia, 16: 108-109.

Poggiani L. \& Dionisi V., 2019 - Gli uccelli del bacino del Metauro 1979-2019. Fondazione Cassa di Risparmio di Fano, Fano.

Poggiani L., Dionisi V. \& Cavalieri C., 2014 - Aves. Uccelli acquatici del basso Metauro. Fondazione Cassa di Risparmio di Fano.

Poggiani L., Dionisi V. \& Gubellini L., 2004 - Ambiente, flora e fauna del litorale di Fano. Assessorato Ambiente, Comune di Fano e Associazione Naturalistica Argonauta, Fano.

Poggiani L., Dionisi V. \& Gubellini L. (a cura di), 2007 Boschi di fiume. Ambiente, flora e fauna dei boschi ripariali del Metauro. Provincia di Pesaro e Urbino, Pesaro.

Premuda G., Gustin M., Pandolfi M., Sonet L. \& Cento M., 2008 Spring raptor migration along the Adriatic coast (Italy): a comparative study over tree sites, Avocetta, 32: 13-20.

Salvadori T., 1887 - Elenco degli uccelli italiani. Annali del Museo Civico di Storia Naturale di Genova, Genova, serie 2, 3.

Simoncini A., Papi D. \& Ruggeri E, 2018 - Bird of the Entella river (Genoa, Italy): a qualitative assessment of bird diversity in an urbanizing biotope, with implications for management and conservation. Rivista Italiana di Ornitologia, 88 (2):11-22.

Spina F. \& Volponi S., 2008 - Atlante della Migrazione degli Uccelli in Italia. 1. non-Passeriformi / 2. Passeriformi. Ministero dell'Ambiente e della Tutela del Territorio e del Mare, Istituto Superiore per la Protezione e la Ricerca Ambientale (ISPRA). Tipografia CSR, Roma, voll. 1-2.

Taylor P. D., Fahrig L., Heinen K. \& Merriam G., 1993 - Connectivity is a vital element of landscape structure. Oikos, 68: 571-573.
Termine R., Canale E. D., Ientile R., Cuti N., Di Grande S. C. \& Massa B., 2008 - Vertebrati della Riserva Naturale Speciale e Sito di Importanza Comunitaria Lago di Pergusa. Naturalista Siciliano, XXXII (1-2).

Tischendorf L. \& Fahrig L., 2000 - On the usage and measurement of landscape connectivity. Oikos, 90: 7-19.

\section{SUPPORTING INFORMATION}

Additional Supporting Information may be found online for this article.

S1: Check-list of the birds of Metauro river estuary and his lower course (Fano, PU) up to September 2020. / Lista completa della specie ornitiche della foce del Metauro e del suo basso corso (Fano, PU) aggiornata a Settembre 2020. 